Rada Varga, The Peregrini of Roman Dacia (106-212), Mega Publishing House, Cluj-Napoca, 2014, pp. 168, ISBN 978-606-543-404-2.

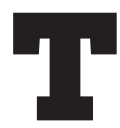

he present book is composed of six chapters and final conclusions of the achieved results, the onomastic catalogue, the epigraphic supplement, respectively the abbreviations and bibliography used.

The first part, entitled Historiographic and Methodological Coordinates (pp. 9-11), represents a historiographical introduction into the researched subject. Also this chapter explains the methodology used in writing this book. It underlines the fact that up to this point Romanian researchers have not done such an analysis and that the studies making references to the peregrines from Dacia are either general, or centered on small groups and/or particular case.

The second part (The Peregrine status, pp. 13-45) contains a trove of information about the peregrines from the Roman Empire. It is here that we find out information about peregrine status and the rights they had in society. The present chapter presents and analyses objectively firstly the Roman laws from the Empire directly or indirectly connected with the peregrines' rights (Tabula Heracleensis - Lex Iulia Municipalis; Lex Aelia Sentia; Lex Ursonensis; Lex Salpensana; Lex Irnitana; Lex Malacitana; Lex Calpurnia; Lex Rubria; Lex provinciae), secondly the legislative act Constitutio Antoniniana that, as we know, changes their status, and thirdly the literary sources used (Gaius, Institutiones; Domitius Ulpianus, Liber Singularis Regularum). The present chapter is enriched with the specific bibliography for these laws, ancient sources, respectively major papers that presented this most heterogeneous group of Roman society.

The third part entitled Population studies and epigraphic representativeness (pp. 47-58), underlines that the importance of demographic studies for Roman antiquity is undebatable -this phrase constitutes the main basis for the whole chapter. Examples concerning the demographic perspective of the Roman Empire are discussed here (Britannia, Hispania, Rome), respectively it presents the importance of epigraphy and of its objective study. However the author claims that it cannot be used as a single source for demographic recreations but that it has to be analyzed together with archaeological sources.

The fourth part Overview of the Peregrines from Dacia (pp. 59-86), presents in detail the peregrines attested in Dacia based on epigraphic monuments. Practically this chapter focuses the discussion on Dacia after an introduction with a lot of information about the peregrines. It is interesting the analysis made on the Roman cities of Apulum, Sarmizegetusa, Porolissum, Arcobadara, Gherla and Alburnus Maior with regards to the percentage of Roman, slave and peregrine population. At Apulum and Sarmizegetusa the percentage is almost the same in that here we find the highest percentage of attested Roman citizens. Here we also find the lowest percentage of peregrines of all the analyzed cities. The highest percentage is encountered at Alburnus Maior, also in Gherla where according to the author's statistics no sclaves are encountered. Another conclusion drawn about these two cities that is worthy of mentioning concerns the higher percentage of peregrines over that of Roman citizens. It is interesting to observe the ethnic origin of

\section{Imola Boda}

Centre for Roman Studies

University „Babeş-Bolyai” of Cluj-Napoca boda_imola@yahoo.com

DOI: http://dx.doi.org/10.14795/j.v1i2.45

ISSN $2360-266 \mathrm{X}$

ISSN-L 2360 - 266X 
peregrines following onomastic analysis: according to the statistics individuals of Roman origin predominate, following (in descending order) those of Illyrian, Greek, Celtic, Thracian, Semitic and Dacian origin - 1\%. All are presented and analyzed in the subchapters dedicated to the ethnic origin of peregrines. The five peregrine women (Serena Licconis, Lucilla Musa, Marciana, Plaetoria Maxima and Quieta), are treated separately, respectively in the subchapter Special cases those individuals whose origin is difficult to interpret

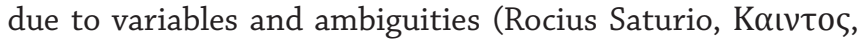
Za $\mu \alpha \nu \nu ı \theta \varepsilon \varsigma$, Daphnus, Tamarcianus, Acilius Sabini f. Dubitatus, Mucatra, Mucapor, Eufemus, Erastus, Bebeia, Blasa, Pacutianus, Bocenus, Prinada, Andrada, Meatinus, Birsi, Atasa, Thiamponius Dexaei f. Besso, Amaiona Aeconis, Cassia Peregrina, Eros Zotici, Procula Batava, Germanus, Zacca Pallaei f. Syrus and Cotu Successi f (ilia) cives Norica).

After this the author presents those peregrines part of an auxiliary unit from Dacia, the chapter being entitled Military Peregrines (pp. 87-98). Here she analyses, based on epigraphic monuments, firstly the ethnic origin of individuals (Roman, Celtic, Thracian, Semitic, Greek, Illyrian, Germanic, Iranian and Dacian) and secondly the gods worshipped by the peregrine soldiers: Iupiter Optimus Maximus, Minerva Augusta and Genius cohortis, Silvanus Domesticus, Nemesis, Victoria Victrix, Deus Aeternus and Placida Regina. The votive inscriptions analyzed indicate that the official gods of Rome are worshipped, military gods and Oriental cults being identified as personal expressions of the dedicant.

In the previous chapters the author discussed those settlements from Dacia where peregrines are attested. From this analysis it stands out that the largest groups of attested peregrines can be found in Alburnus Maior. Next, part six of the book entitled Peregrine Communities (pp. 99-113) presents the community from Alburnus Maior. The persons who appear on votive and funerary monuments, wax tablets respectively military diplomas. The structure of this chapter is similar to the others: the author analyzes the ethnic origin of peregrines, the relation between the individuals, its function, respectively the divinities they worshipped (in descending order: Iupiter, Silvanus, Apollo, Liber Pater, Diana, Asclepius, Nymphae, Ianus, Mercurius, Terra Mater, Genius Sardiate).

In the final part we find the final conclusions of the book (pp. 115-116). It is here that the most important ideas and information are concentrated. According to the author: "Concluding, two aspects seem to be fundamental: who were the attested peregrini and what was their place within the provincial society. Officially defined rather by the rights they do not enjoy, peregrines find various means of integration and make use of multiple means of expression that indicate their enormous cultural plurality."

At the end of the book we find a catalogue (pp. 117-137), very well structured, its purpose being to synthesize the whole book in a single table where the names are listed (398 names), their origin, filiation, military troop, status and relations, the gods they worshipped. Also the type of monument, the author's remarks, place of discovery, respectively bibliography are written here (pp. 139-152). The corpus is made up of a total of 269 epigraphic monuments and contains the following: current number, source and the inscription.
The book is enriched with XIII statistical tables found inside it, their main purpose being to incorporate and present the essential results, thus facilitating the understanding the details. Here she analyses: epigraphic proportions of juridical categories in Dacia (I); the epigrafic presence of peregrines (II); the quantitative allocation of source types (III); ethnic origin of the peregrine name, general (IV); ethnic origin of peregrine names, excluding Alburnus Maior (V); comparative onomastic overview (VI); comparative graph for dedicants of funerary monuments (VII); ethnic origin of the names attested in connection to the auxiliary troops of Dacia (VIII); comparative percentages of the names of soldiers and the names of the other characters from the military environment (IX); epigraphic rapport peregrines-citizens at Alburnus Maior (X); onomastic of votive dedications (XI); divinities for which votive monuments were set up (XII), and ethnic origin of the peregrine names from Alburnus Maior (XIII).

What the present study did not determine was the impact of the changes of 212 on Dacia. To this end the author states that it is possible that in Dacia, as well, the good juridical integration of peregrines played its significant role and the legitimizing of a new citizen status came as a formality. Probably the paper could have offered a more ample image if it would have contained information about some other settlement from the Roman Empire, thus comparing the situation from Alburnus Maior. Despite this small setback the present paper entitled The Peregrini of Roman Dacia (106212) is a reference book for all those interested in the Roman period, respectively social history as well as for future studies intended on analyzing peregrines from the different provinces of the Roman Empire. 